\title{
PENGEMBANGAN APLIKASI MULTIMEDIA INTERAKTIF PEMBUDIDAYAAN TANAMAN TOMAT
}

\author{
Oleh \\ Ni Wayan Marti \\ Jurusan Manajemen Informatika, FTK - UNDIKSHA
}

\begin{abstract}
Abstrak
Tanaman tomat merupakan salah satu tanaman yang diminati untuk dibudidayakan, karena buah tomat mengandung vitamin, mineral, karbohidrat, protein, lemak dan kalori yang diperlukan tubuh untuk pertumbuhan dan kesehatan. Dalam artikel ini dikembangkan sebuah aplikasi multimedia interaktif pembudidayaan tanaman tomat yang dikemas dalam bentuk CD interaktif. Adapun informasi yang disajikan dalam media ini adalah proses pembudidayaan tanaman tomat, yang meliputi pembibitan, pengolahan media tanam, penanaman, perawatan, pemanenan dan pemasaran komuditinya.
\end{abstract}

Kata kunci : tanaman tomat, budidaya, CD interaktif, multimedia

\begin{abstract}
Tomato plants are one of the preferred plant for cultivated, because tomatoes contain vitamins, minerals, carbohydrates, protein, fat and calories the body needs for growth and health. In this article developed an interactive multimedia application of tomato cultivation that is packed in the form of an interactive CD. The information presented in this medium is the process of tomato crop cultivation, including breeding, processing of the planting medium, planting, care, harvesting and marketing komuditinya.
\end{abstract}

Kata kunci : tomato plans, cultivation, interactive $\mathrm{CD}$, multimedia

\section{PENDAHULUAN}

Budidaya adalah proses dimana tanah digemburkan dan dilembekkan dengan menggunakan tangkai kemudi ataupun penggaru yang ditarik oleh traktor maupun bajak yang ditarik oleh binatang maupun manusia. Melalui proses ini, kerak tanah teraduk, sehingga udara dan cahaya matahari menembus tanah dan meningkatkan kesuburannya. Sekalipun demikian, tanah yang sering digarap sering menyebabkan kesuburannya berkurang (http://www.id.wikipedia.org). 
Semula, tujuan manusia melakukan budidaya tanaman adalah untuk memenuhi kebutuhan pangan yang terus meningkat seiring dengan pertambahan jumlah penduduk yang semakin cepat. Karena itu, penelitian-penelitian terhadap budidaya tanaman terus dilakukan untuk mendapatkan tanaman unggul, yakni berproduksi tinggi, responsif terhadap pemupukan, dan mempunyai ketahanan terhadap serangan hama dan penyakit tanaman (Endah, 2002).

Dari sekian banyaknya jenis tanaman yang dibudidayakan, tomat merupakan salah satu tanaman yang diminati untuk dibudidayakan. Karena selain sangat bermanfaat bagi tubuh tomat juga mengandung vitamin, mineral, karbohidrat, protein, lemak dan kalori yang diperlukan untuk pertumbuhan dan kesehatan, buah tomat juga merupakan komoditas multiguna yang berfungsi sebagai sayuran, bumbu masak, buah meja, penambah nafsu makan, minuman, bahan pewarna makanan, sampai pada bahan kosmetik dan obat-obatan.

Pengetahuan mengenai pembudidayaan dari tanaman tomat ini, masih banyak yang belum mengetahui dengan baik. Untuk itu, pengetahuan mengenai pembudidayaan ini perlu disebar salah satunya dengan memanfaatkan teknologi yang telah berkembang semakin pesat saat ini. Salah satunya yaitu membuatkan sebuah media elektronik yang dikemas dalam bentuk CD interaktif.

Untuk itulah dalam artikel ini akan dibahas mengenai pembuatan CD Interaktif proses pembudidayaan tomat yang meliputi pembibitan, pengolahan media tanam, penanaman, pemeliharaan, pemanenan, dan pemasaran hasil panen. CD interaktif ini dibuat menggunakan perangkat lunak macromedia flash 8.

\section{LANDASAN TEORI}

\section{Pengertian Budidaya}

Budidaya adalah proses dimana tanah digemburkan dan dilembekkan dengan menggunakan tangkai kemudi ataupun penggaru yang ditarik oleh traktor maupun bajak yang ditarik oleh binatang maupun manusia. Melalui proses ini, kerak tanah teraduk, sehingga udara dan cahaya matahari menembus tanah dan meningkatkan kesuburannya. Sekalipun demikian, tanah yang sering digarap sering menyebabkan kesuburannya berkurang(http://www.id.wikipedia.org).

JPTK, UNDIKSHA, Vol. 7, No. 1, Januari 2010 : 29 - 40 


\section{Tanaman Tomat}

Tanaman tomat adalah salah satu jenis sayuran yang banyak digemari orang karena rasanya enak, segar dan sedikit asam. Buah tomat mengandung vitamin (A, C dan sedikit vitamin B), mineral, karbohidrat, protein, lemak dan kalori yang diperlukan untuk pertumbuhan dan kesehatan (http://www.pustaka-deptan.go.id, 1993). Selain itu, tomat juga kaya akan antioksidan yang sangat baik untuk menjaga kesehatan tubuh. Salah satu kandungan di dalam tomat yang paling bermanfaat adalah lycopene. Lycopene merupakan salah satu jenis antioksidan vital alami. Antioksidan ini merupakan bagian dari keluarga pigmen yang disebut dengan karoten. Karoten merupakan komponen alami yang menimbulkan adanya warna pada buah dan sayuran. Studi-studi telah membuktikan kalau tomat tidak hanya efektif mencegah kanker tetapi juga mencegah penyakit jantung dan kolesterol tinggi. Kanker prostat, kanker rektal, kanker perut, mulut, kerongkongan telah terbukti bisa dicegah dengan mengkonsumsi lycopene dalam jumlah banyak. Para peneliti memasukkan lycopene ke dalam kultur sel-sel kanker. Lycopene terbukti bisa mencegah pertumbuhan kultur sel-sel kanker ini. Hal ini merupakan bukti kuat yang menunjukkan manfaat tomat bagi kesehatan.

\section{Multimedia}

Mengutip dari Robin dan Linda, dalam Suyanto (2004) mengartikan multimedia adalah alat yang dapat menciptakan presentasi yang dinamis dan interaktif yang mengkombinasikan teks, grafik, animasi, audio, dan gambar video. Definisi lain dari multimedia, yaitu dengan menempatkannya dalam konteks, seperti yang dilakukan Hofstetter (dalam Suyanto, 2004), multimedia adalah pemanfaatan komputer untuk membuat dan menggabungkan teks, grafik, audio, gambar bergerak (video dan animasi) dengan menggabungkan link dan tool yang memungkinkan pemakai melakukan navigasi, berinteraksi, berkreasi dan berkomunikasi. Kelebihan Inilah yang menyebabkan tampilan multimedia lebih dinamis dan menyenangkan bagi pemakai.

Multimedia dapat dibagi menjadi dua kategori yaitu multimedia content production dan multimedia communication. 


\section{a. Multimedia Content Production}

Multimedia adalah penggunaan dan pemrosesan beberapa media (text, audio, graphics, animation, video, and interactivity) yang berbeda untuk menyampaikan informasi atau menghasilkan produk multimedia (music, video, film, game, entertaiment, dan lain-lain). Atau penggunaan sejumlah teknologi yang berbeda yang memungkinkan untuk menggabungkan media (text, audio, graphics, animation, video, and interactivity) dengan cara yang baru untuk tujuan komunikasi. Dalam kategori ini media yang digunakan adalah seperti yang terlihat pada Gambar 1 berikut ini :

\section{Multimedia Production}

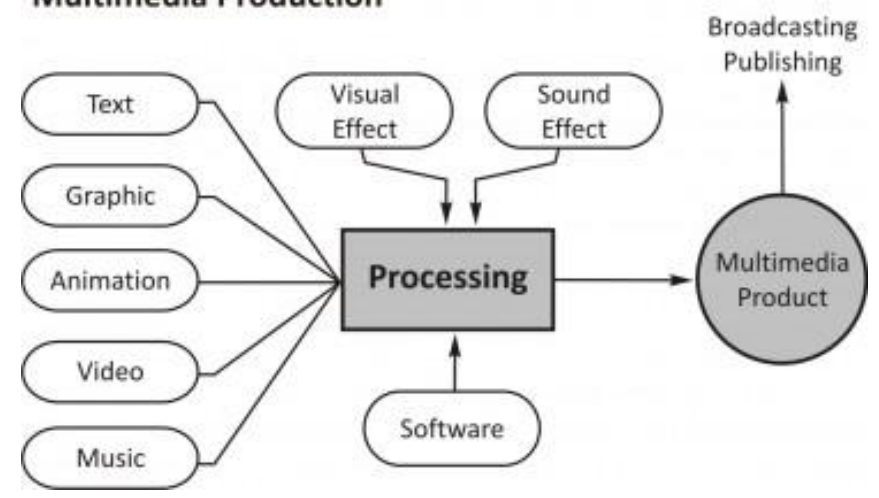

Gambar 1: Multimedia Production.

\section{b. Multimedia Communication}

Multimedia adalah penggunaan media (masa), seperti televisi, radio, cetak, dan Internet, untuk mempublikasikan / menyiarkan / mengkomunikasikan material periklanan, public-city, hiburan, berita, pendidikan, dan lain-lain. Dalam kategori ini media yang digunakan adalah seperti yang terlihat pada Gambar 2 berikut ini : 


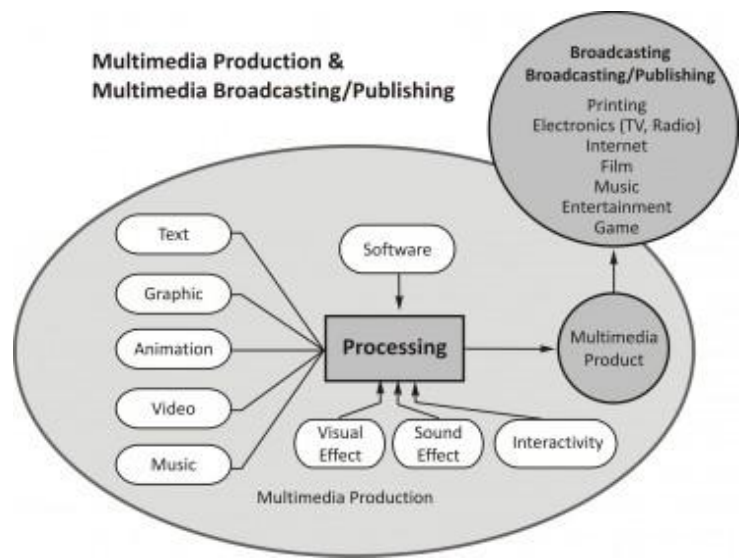

Gambar 2: Multimedia Production dan Multimedia Broadcasting/Publishing.

\section{Interaktif}

CD Interaktif merupakan sebuah media yang menegaskan sebuah format multimedia dapat dikemas dalam sebuah CD (Compact Disk) dengan tujuan aplikasi interaktif di dalamnya. CD ROM (Read Only Memory) merupakan satu-satunya dari beberapa kemungkinan yang dapat menyatukan suara, video, teks, dan program dalam CD.

Dari sini jelas bahwa sistem interaktif yang dipakai CD Interaktif sama persis dengan sistem navigasi pada internet, hanya yang berbeda di sini adalah media yang dipakai keduanya. CD Interaktif memakai media off line (tanpa jaringan) berupa CD sementara internet memakai media on line (aktif di jaringan). Bentuk CD Interaktif dengan tampilan yang tetap menarik hanya dapat digunakan pada lokal satu unit PC (Personal Computer) saja. Sedangkan

Membuat halaman CD interaktif tak ubahnya seperti membuat halaman web karena secara umum halaman web sama dengan halaman CD interaktif, hanya medianya saja yang berbeda. Dengan demikian kaidah-kaidah yang ada pada CD Interaktif dan web adalah sama. Seorang desainer menggunakan elemen-elemen pokok agar sebuah desain dapat secara efektif menyampaikan tujuannya. Elemenelemen yang digunakan tersebut antara lain adalah tipografi, simbolisme, ilustrasi dan fotografi (Istanto, 2001:57). Sedangkan menurut Budi Sutedjo Dharma Oetomo (Oetomo, 2001) menyatakan ada 10 unsur yang dapat digunakan untuk merancang sebuah halaman CD Interaktif yang cantik dan artistik, yaitu huruf, warna, gambar, 
model kartun, foto, animasi, tiga dimensi, bentuk-bentuk geometri, tekstur, dan manusia. Dari berbagai pendapat itu maka dapat disimpulkan ada beberapa elemen yang sangat vital dalam proses perancangan sebuah CD Interaktif yang artistik dan efektif, diantaranya adalah: tipografi, simbolisme, ilustrasi, warna, fotografi, animasi, nuansa, dan halaman depan (Beni, http://deskomers01.com).

\section{Aplikasi Multimedia Budidaya Tanaman Tomat}

Aplikasi multimedia budidaya tanaman tomat merupakan sebuah media informasi yang dikemas dalam bentuk CD multimedia interaktif. Selain menampilkan teks, media informasi ini dilengkapi dengan gambar dan video dalam penyajian informasinya. Selain itu, media informasi ini dilengkapi dengan fasilitasi bilingual (dua bahasa) yaitu bahasa Indonesia dan bahasa Inggris. Adapun informasi yang yang diperoleh dari media informasi ini adalah proses pembudidayaan tanaman tomat, yang meliputi pembibitan, pengolahan media tanam, penanaman, perawatan, pemanenan dan pemasaran komuditinya. Dalam proses pembibitan dijelaskan mengenai penyebaran benih sampai dengan benih tumbuh menjadi bibit yang siap tanam. Dalam proses pengolahan media tanam dijelaskan mengenai persiapan waktu untuk pembukaan lahan untuk media tanam tanaman tomat sampai dengan pemasangan plastik mulsa yang nantinya akan dilubangi sebagai tempat penanaman bibit tomat. Dalam proses penanaman dijelaskan mengenai pemindahan bibit tanaman tomat yang siap tanam ke media tanam dengan memperhatikan waktu penanaman, cuaca, cara penanaman dan pola penanaman. Dalam proses perawatan dijelaskan mengenai pemupukan, pembasmian hama, penyiraman, pemasangan lanjaran (tungguan), pengikatan terhadap batang yang telah tumbuh panjang. Dalam proses pemanenan dijelaskan mengenai ciri dan umur panen, cara panen, periode panen tanaman tomat. Dalam proses pemasaran dejilaskan tentang pemasaran tanaman tomat setelah dipanen.

\section{DESAIN APLIKASI MULTIMEDIA INTERAKTIF}

Dalam pengembangan CD multimedia interaktif pembudidayaan tanaman tomat ini meliputi 6 tahapan, yaitu: konsep, disain, pengumpulan material, pembuatan

JPTK, UNDIKSHA, Vol. 7, No. 1, Januari $2010: 29$ - 40 
(assemby), testing, dan distribusi (Luther, 1994). Tahapan-tahapan tersebut dapat dilihat pada Gambar 3 berikut ini.

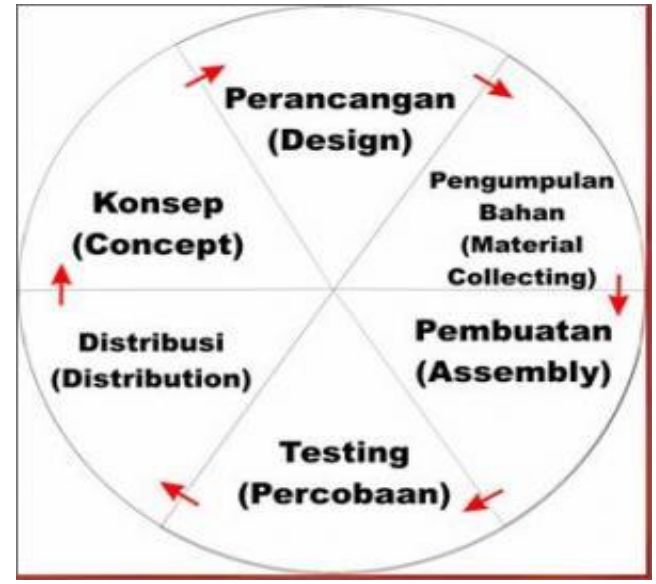

Gambar 3: Tahap pengembangan aplikasi multimedia interaktif menurut Lutther (1994)

\section{Konsep (Concept)}

Tahap konsep merupakan tahap awal dari pengembangan multimedia interaktif. Dalam tahap ini yang paling utama adalah penentuan ide dasar program yang akan dikembangkan.

\section{Perancangan (Desain)}

Pada tahap ini akan dibuat bagan alir (Flow Chart) yang menggambarkan struktur dari aplikasi multimedia interaktif pembudidayaan tanaman tomat yang dibuat secara rinci dan pembuatan storyboard untuk pemetaan elemen-elemen atau bahan (material) multimedia pada setiap layar aplikasi multimedia.

\section{Pengumpulan bahan materi program (Material Collecting)}

Pada tahap ini dilakukan pengumpulan bahan (material) seperti: clipart, image, animasi, audio, berikut pembuatan grafik, foto, audio, dan lain-lain yang menunjang aplikasi mutimedia interaktif pembudidayaan tanaman tomat ini.

\section{Pembuatan (Assembly)}

Tahap assembly merupakan tahap dimana seluruh objek multimedia dibuat. Dalam tahap ini objek material seperti text, gambar, audio, video dan material lain yang telah dikumpulkan dijadikan sebuah program yang terstruktur sesuai dengan storyboard 
dan flow chart yang telah dibuat sebelumnya.Dalam hal ini, software yang digunakan adalah Macromedia Flash.

\section{Percobaan (Testing)}

Testing dilakukan setelah tahap pembuatan selesai seluruhnya. Pertama-tama dilakukan testing secara modular untuk memastikan apakah hasilnya seperti yang diinginkan. Selanjutnya jika ada kesalahan, program tersebut diperbaiki. Jika sudah sesuai maka dapat berlanjut pada tahap berikutnya.

\section{Distribusi (Distribution)}

Tahapan ini maksudnya adalah menyimpan data hasil program ke dalam media yang dapat dikonsumsi oleh banyak orang. Media yang digunakan biasanya berupa CDROM. Proses ini dinamakan pula sebagai proses pembakaran CD (burning).

\section{HASIL DAN PEMBAHASAN}

Produk yang dihasilkan dalam penelitian ini adalah sebuah aplikasi multimedia interaktif pembudidayaan tanaman tomat yang dikemas dalam bentuk CD interaktif. Pada media ini disajikan informasi-informasi mengenai tahapan-tahapan yang dilakukan pada proses pembudidayaan tanaman tomat mulai dari proses pembibitan, pengolahan media tanam, penanaman, perawatan, pemanenan dan pemasaran buah tomat itu sendiri. Selain itu dilengkapi pula informasi tentang seputar Desa Pancasari yang merupakan tempat pengambilan data dilakukan dan informasi tentang tanaman tomat itu sendiri.

Adapun secara rinci dari penyajian informasi pada aplikasi multimedia ini adalah sebagai berikut :

\section{Tampilan Awal}

Ketika pertama kali CD Interaktif dijalankan, maka akan muncul tampilan ucapan selamat datang seperti yang terlihat pada gambar 4 berikut ini. 


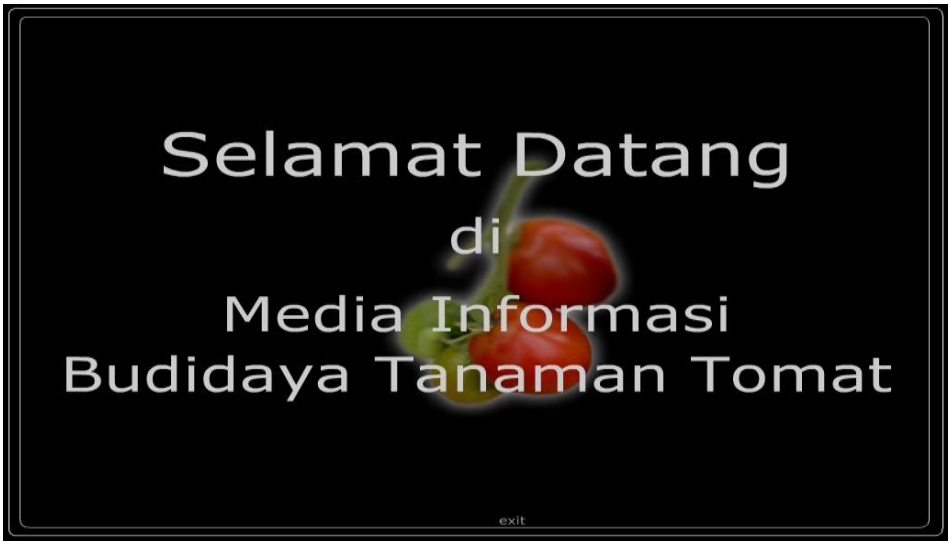

Gambar 4. Tampilan Ucapan Selamat Datang

Tampilan di atas dikemas dalam dua bahasa yaitu Bahasa Indonesia dan Bahasa Inggris yang ditampilan secara bergantian. Dilanjutkan dengan tampilan untuk pilihan bahasa.

\section{Pilihan Bahasa}

Informasi yang disediakan pada aplikasi multimedia ini disajikan dalam dua pilihan bahasa yaitu bahasa Indonesia dan bahasa Inggris. Dimana tampilan dari pilihan bahasa ini dapat dilihat pada gambar 5 berikut ini.

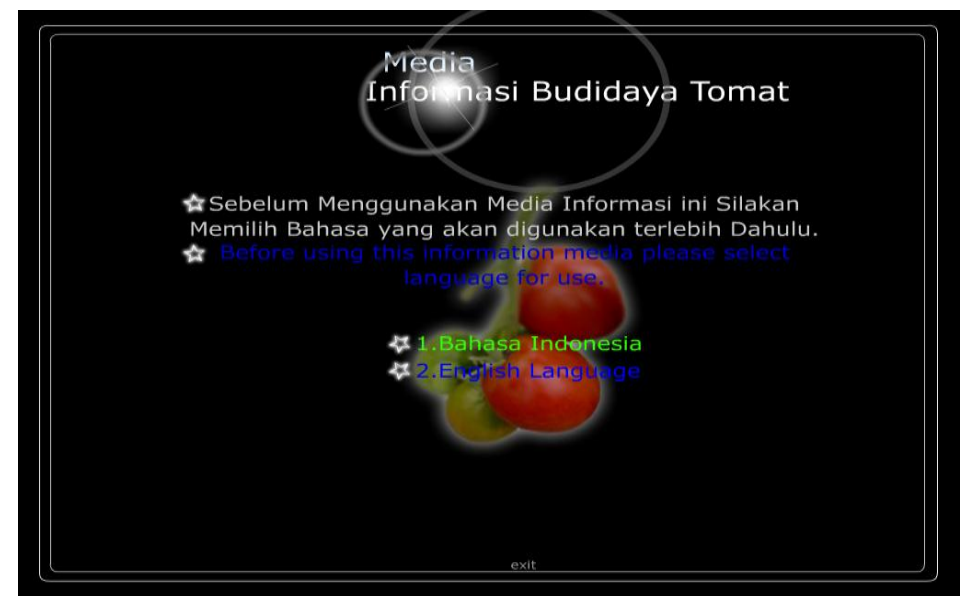

Gambar 5. Tampilan pilihan bahasa

Pada tampilan di atas, pengguna dapat memilih salah satunya bahasa cukup dengan mengklik salah satu option bahasa yang telah disediakan. Setelah memilih salah satu bahasa yang disediakan maka pengguna akan masuk ke tampilan menu utama. 


\section{Tampilan Intro}

Tampilan intro pada gambar 6 akan dimunculkan sebelum masuk ke tampilan menu utama. Intro ini ditayangkan dengan durasi waktu sekitar 1 menit.

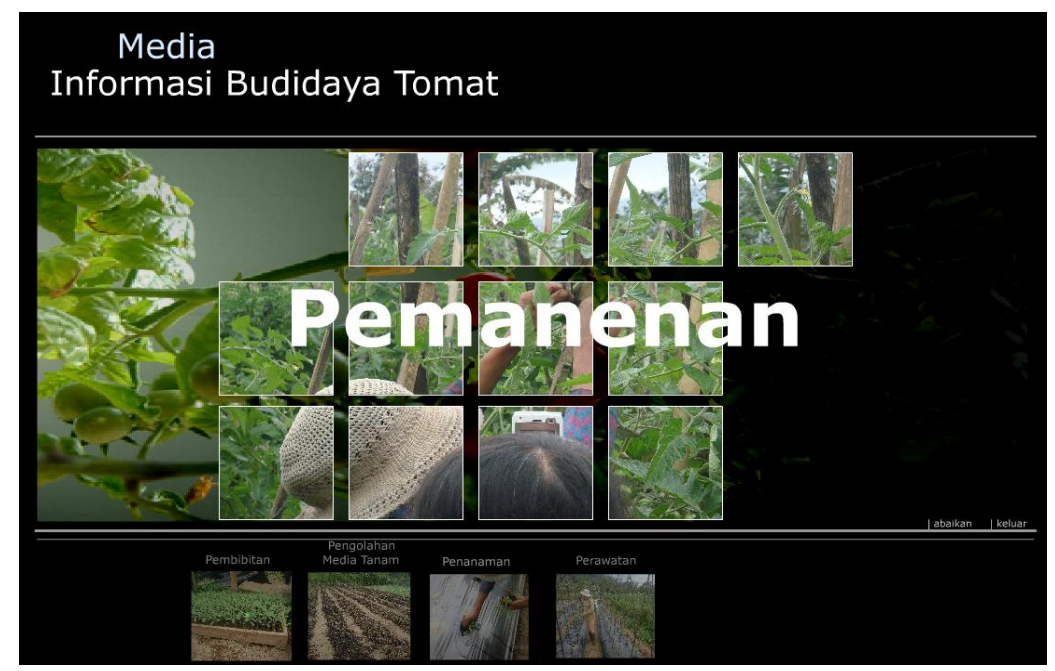

Gambar 6. Tampilan Intro

\section{Tampilan Menu Utama}

Pada tampilan ini berisi tentang daftar menu-menu yang akan dijelaskan dalam aplikasi multimedia ini. Terdapat 4 (empat) menu yaitu Beranda, Proses Budidaya, Sekilas Desa Panca Sari dan Sekilas Tanaman Tomat. Adapun tampilan menu utama tersebut dapat dilihat seperti pada gambar 7 berikut ini.

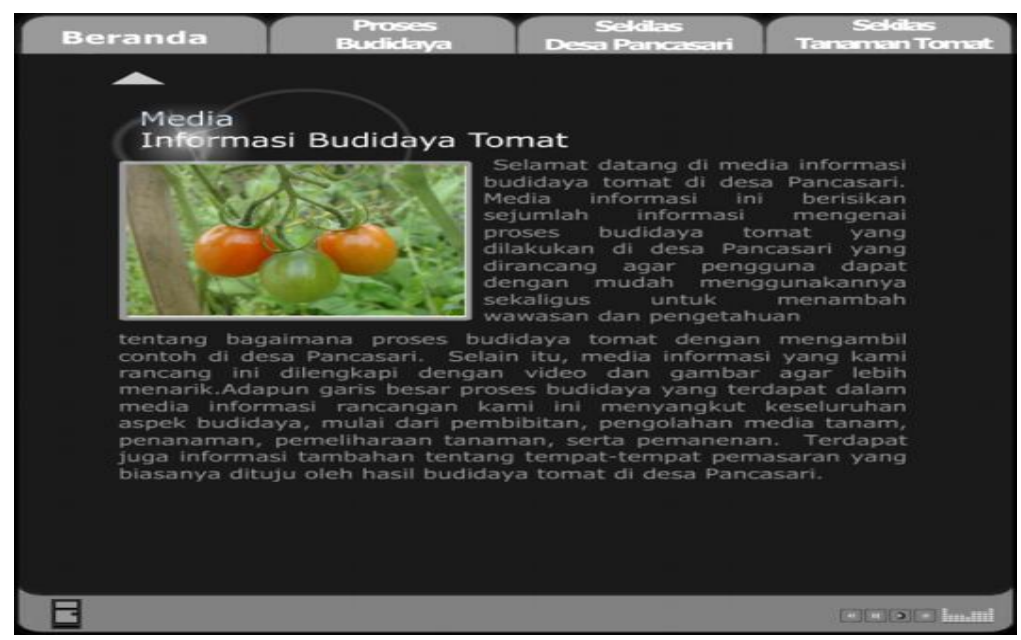

Gambar 7. Tampilan Menu Utama

JPTK, UNDIKSHA, Vol. 7, No. 1, Januari 2010 : 29 - 40 


\section{Tampilan untuk Menu Proses Budidaya}

Pada Gambar 8 berikut ini merupakan tampilan informasi yang disajikan pada menu Proses Budidaya yang meliputi 6 sub menu yaitu Pembibitan, Pengolahan media tanam, Penanaman, Pemeliharaan, Pemanenan dan Pemasaran.

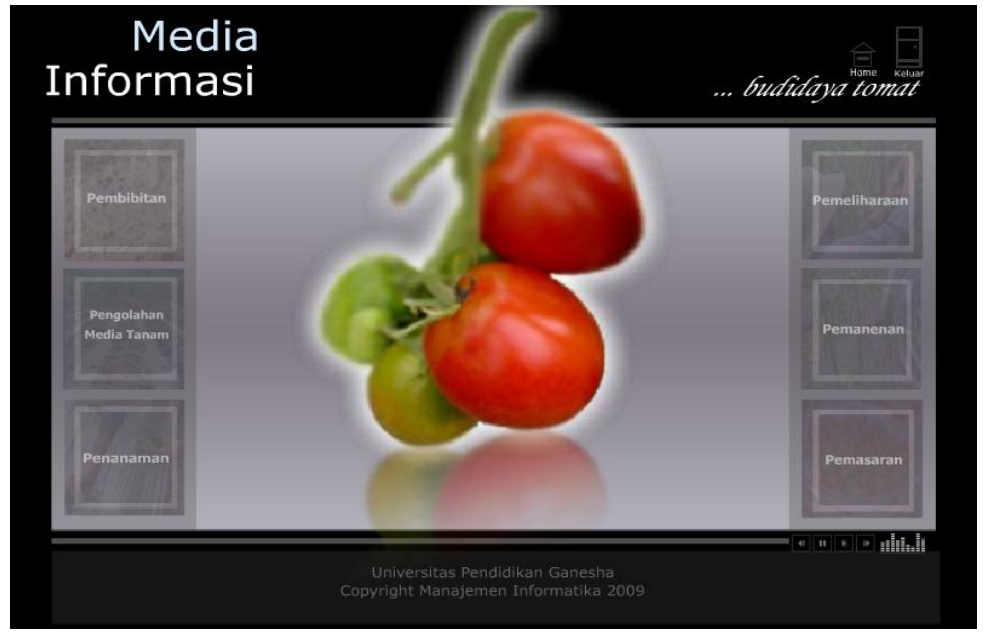

Gambar 8. Tampilan Menu Proses Budidaya

Gambar 9 di bawah ini merupakan tampilan informasi dari sub menu Pembibitan. Pada sub menu pembibitan menampilkan informasi tentang proses pembibitan tanaman tomat dari penyebaran benih sampai dengan benih tumbuh menjadi bibit yang siap tanam. Keluarannya adalah informasi berupa teks, gambar dan video.

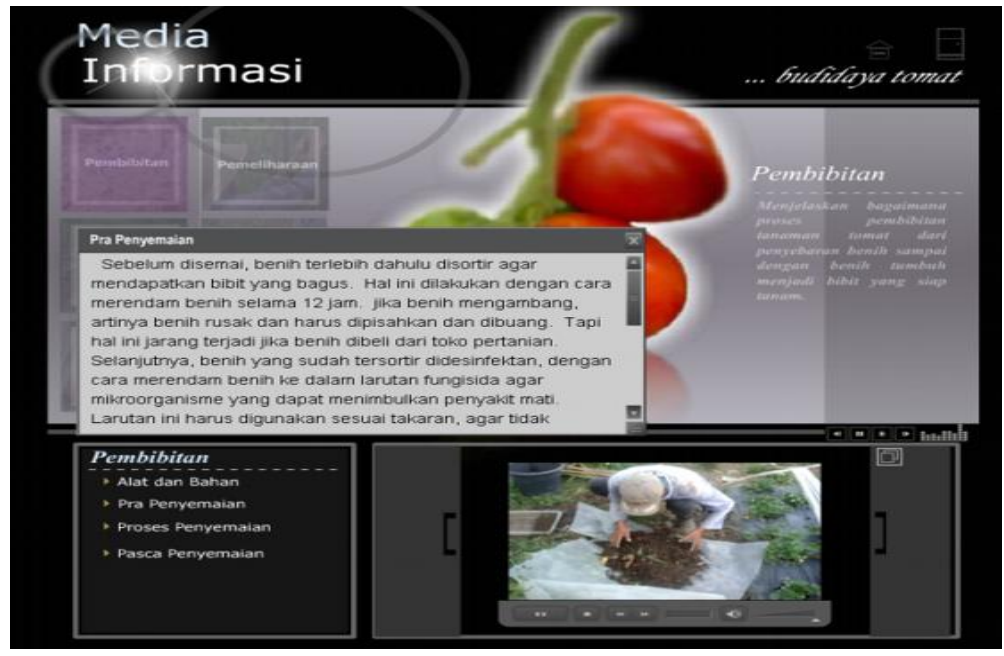

Gambar 9. Tampilan sub menu Pembibitan 
Penyajian informasi untuk sub menu lainnya hampir sama, hanya berbeda materi yang dijelaskan saja. Begitu juga jika memilih tampilan informasi dalam bahasa Inggris hanya bahasanya saja yang berubah.

\section{SIMPULAN}

Aplikasi multimedia interaktif pembudidayaan tanaman tomat yang mengambil kasis di desa Pancasari dibangun menggunakan macromedia flash 8, Adobe Photoshop CS2, Pinacle Studio 12, Xilisoft Video Converter Ultimate 5, Jet Audio Basic 7, dan Ulead Video Studio 11. Materi-materi yang termuat dalam media ini beberapa teori-teori mengenai pembibitan, pengolahan media tanam, penanaman, perawatan, pemanenan, dan pemasaran.

\section{DAFTAR PUSTAKA}

Beni, Dani Maroe. Multimedia. http://deskomers01.com/?p=187, diakses pada tanggal 19 april 2010

Istanto, Freddy H. 2001. Potensi dan Kaidah Perancangan Situs Web Sebagai Media Komunikasi visual. Nirmana, Volume 3. No.1

Lutther, Arc C. 1994. Authoring Interactive Multimedia. Boston : AP Professional.

Misky, Dudi. 2005. Kamus Informasi \& Teknologi. Jakarta: EDSA Mahkota

Suyanto, Muhammad. 2004. Analisis \& Desain Aplikasi Multimedia untuk Pemasaran. Yogyakarta: Andi

1993. Bercocok Tanam Tomat (Lycopersicum esculentum Mill). http://www.pustaka-deptan.go.id/agritek/ppua0145.pdf. diakses tanggal 19 April 2010 